\title{
Comparative Study Between PID and Fuzzy PID Controller for Speed Control of BLDC Motor
}

\author{
Ahmed Hessien Mohamed \\ Electrical Engineering and Computer Control Dept. \\ Arab Academy for Science Technology \& Maritime \\ Transport, Cairo, Egypt
}

\author{
H. E. A. Ibrahim \\ Electrical Engineering and Computer Control Dept. \\ Arab Academy for Science Technology \& Maritime \\ Transport, Cairo, Egypt
}

\begin{abstract}
Because of advantages of BLDC motor, including high accuracy, low volume, and clear control characteristic is still using in a wide range of industrial application. This paper presents comparative study of the Classical Proportion Integral Derivative Controller (PID) and Fuzzy self-tuning PID for speed control of BLDC. With rising complexity and accuracy of control systems, only using FLC or PID cannot satisfy the required operating conditions for such speed control of such type of machines. Fuzzy self-tuning PID controller is presented as a solution of this problem. Fuzzy self tuning PID improves the overall system performance including time response. The modeling, control and simulation of BLDC motor have been done using MATLAB/SIMULINK package.
\end{abstract}

Keywords- Brushless DC Motor (BLDC); Proportional Integration Derivative (PID Controller); Fuzzy Logic Controller (FLC); Fuzzy Self-Tuning PID;

\section{INTRODUCTION}

Now a day, BLDC motor becomes very important in markets and widely used in automotive, computer, industrial, aerospace etc. DC motor need brushes for commutation, but The BLDC motor does not needs any brushes for commutation, because the BLDC motors are electronically commutated. BLDC motors have several advantages over brushed dc motor (High reliability and efficiency, lighter and smaller, lower acoustic noise, greater dynamic response, better speed vs. torque characteristics, longer life and higher speed range).

Permanent magnet brushless DC motor speed control is a nonlinear, multivariable, time-varying system and the parameter tuning is too difficult. When we use the conventional controller, it is difficult to meet the requirements. Due to these results, we use the intelligent controllers. Since 1965, the Uuniversity of California cybernetics expert Zadeh proposed fuzzy since its theories and methods of improving, just a few decades, and the fuzzy control is widely used in the natural, social sciences and engineering control field. Fuzzy logic has a natural language skills similar to the human brain, is very suitable for nonlinear systems [1].

Fuzzy logic control does not depend on the accurate mathematical model of the controlled object, it is possible to overcome the influences of nonlinear factors on the adjustment object parameter changed have robust, but the summary of fuzzy rules and fuzzy membership tuning function rely mainly on experience, greater subjectivity.
This paper presents a model that is based on fuzzy self-tuning PID control of brushless dc motor speed control system. The error and deviation of error act as the input parameters of the fuzzy control inference engine, with the fuzzy theory PID parameters online is adaptively adjusted and control system made simulation experiment in MATLAB/SIMULINK. The simulation results show that fuzzy self-tuning PID controller givesa fast response, a small overshoot, a small steady state error, and the dynamic characteristics are better than PID control. The motor drive consists of speed controller, current controller and position sensors as show in Fig.1

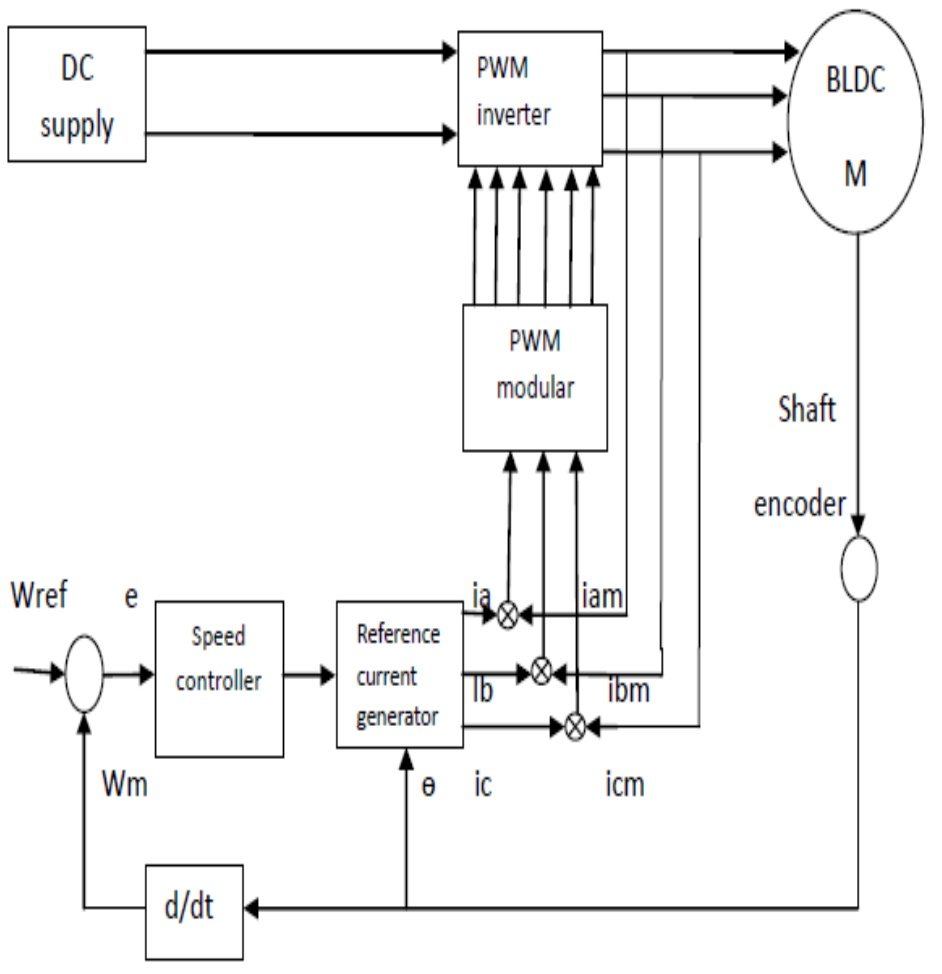

Figure (1): Block diagram of BLDCM

\section{PRINCIPLE OF OPERATION}

BLDC motor is a type of permanent magnet synchronous motor, which uses position detectors and an inverter tocontrol the armature currents. BLDC motor is referred to asan inside out dc motor, since its armature is in the stator and the magnets are on the rotor and its operating characteristicsresemble that of a dc motor. Mechanical commutators are used in case of DC motors, where as the commutation is done 
Through electronically in BLDC motor, which results in maintenance free, there are two main types of BLDCmotors: trapezoidal type and sinusoidal type. In the trapezoidal motor, the back-emf induced in the stator windings has a trapezoidal shape and its phases must be supplied with quasi-square currents for ripple free operation. The sinusoidal motor on the other hand has a sinusoidally shaped back - emf and requires sinusoidal phase currents for ripple free torque operation. The shape of the back - emf is determined by the shape of rotor magnets and the stator winding distribution [2].

Resolution of the position sensors should be high in case ofsinusoidal motors because the rotor position must be knownat every instant of time for the optimal operation. It also requires more complex software and hardware. The trapezoidal motor is a more attractive alternative for most applications due to simplicity, lower price and higher efficiency. BLDC motors exist in many different configurations but the three-phase motor is most common type due to efficiency and low torque ripple. This type of motor also offers a good compromise between precise control and number of power electronic devices needed to control stator currents. Position detection is usually implemented using three Hall - effect sensors which detect the presence of small magnets that are attached to the motor shaft. This paper presents BLDC motor trapezoidal type [3].

BLDC motor is driven by a three-phase inverter, with this six-step commutation is possible. The conducting interval for each phase is $120^{\circ}$ by electrical angle. Maximum torque is reachedwhen the field lines are perpendicular. The commutation phase sequence is like AB-AC-BC-BA-CA-CB. Each conducting stage is called one step. Therefore, only two phases conduct current at any time, leaving the third phase floating. In order to produce maximum torque, the inverter should be commutated every $60^{\circ}$ so that current is in phase with the back EMF. The commutation timing is determined by the rotor position, which can be detected by Hall sensors as shown in the Fig. $2(\mathrm{H} 1, \mathrm{H} 2$, and $\mathrm{H} 3)$. Current commutation is done by inverter as shown in a simplified form in Fig.3. The switches are shown as bipolar junction transistors but MOSFET switches are more common. Table I shows the switching sequence, the current direction, and the position sensor signals [4].

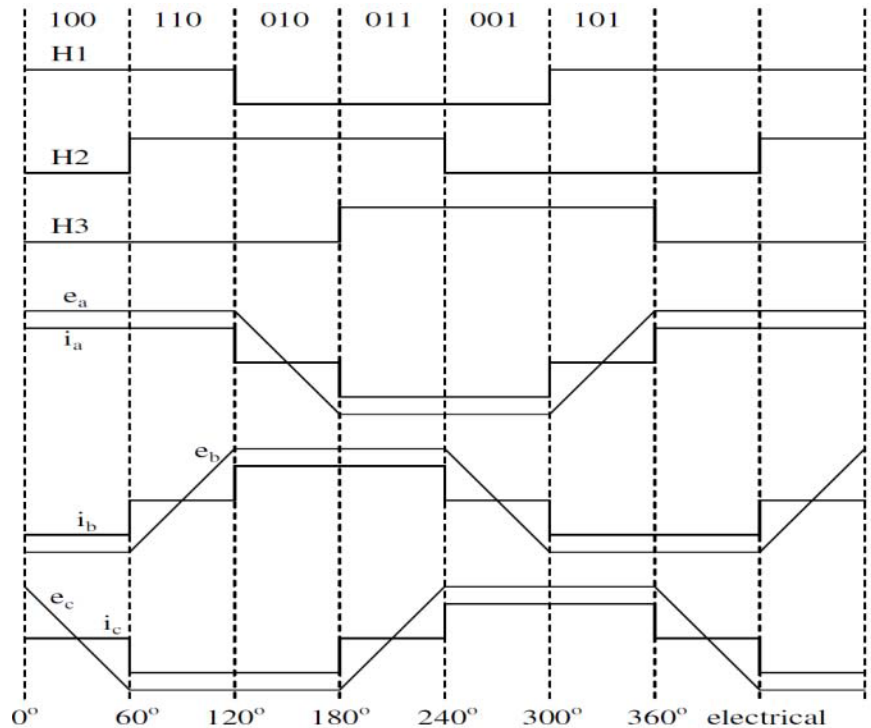

Figure (2): Ideal Back Emf, Phase currents and Position sensor signals

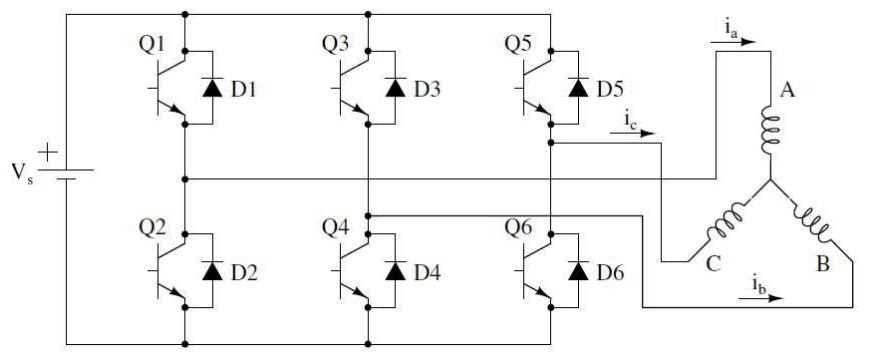

Figure (3): Simplified BLDC Drive Scheme

Table I. Switching Sequence

\begin{tabular}{|c|c|c|c|c|c|c|c|c|c|}
\hline \multirow{2}{*}{$\begin{array}{l}\text { Switching } \\
\text { interval }\end{array}$} & \multirow{2}{*}{$\begin{array}{l}\text { Sequence } \\
\text { number }\end{array}$} & \multicolumn{3}{|c|}{$\begin{array}{l}\text { Position } \\
\text { sensors }\end{array}$} & \multicolumn{2}{|c|}{ Switch } & \multicolumn{3}{|c|}{$\begin{array}{c}\text { Phase } \\
\text { Current }\end{array}$} \\
\hline & & $\mathrm{H} 1$ & $\mathrm{H} 2$ & H3 & clc & ed & $\mathrm{A}$ & $\mathrm{B}$ & $\mathrm{C}$ \\
\hline $0^{\circ}-60^{\circ}$ & 0 & 1 & 0 & 0 & Q1 & Q4 & + & - & Off \\
\hline $60^{\circ}-120^{\circ}$ & 1 & 1 & 1 & 0 & Q1 & Q6 & + & off & - \\
\hline $120^{\circ}-180^{\circ}$ & 2 & 0 & 1 & 0 & Q3 & Q6 & off & + & - \\
\hline $180^{\circ}-240^{\circ}$ & 3 & 0 & 1 & 1 & Q3 & Q2 & - & + & Off \\
\hline $240^{\circ}-300^{\circ}$ & 4 & 0 & 0 & 1 & Q5 & Q2 & - & off & + \\
\hline $300^{\circ}-360^{\circ}$ & 5 & 1 & 0 & 1 & Q5 & Q4 & off & - & + \\
\hline
\end{tabular}

\section{BLDC MOTOR SPEED CONTROLLERS}

There are several controllers available nowadays like proportional integral derivative (PID), the fuzzy logic controller (FLC), neural networks or/and a combination of conventional and intelligent controllers. In this paper, we discuss PID controller and combination between fuzzy logic and PID controller.

\section{A. PID Controller}

Classic PID control has been widely used because of its simple construction and good robustness. In project practice, PID control still takes the dominated place. PID control consists of proportional, integral and derivative as shown in Fig.4.

One of design PID controller challengesis how to choose the controller parameters, can obtain satisfactory results. PID controller is a linear controller. For the control equation:

$e(t)=x(t)-y(t)$ 
The control law for PID controller is:

$u(t)=k_{p} e(t)+k_{i} \int_{0}^{t} e(t) d(t)+k_{d} \frac{d e(t)}{d(t)}$

Where $k_{p}$ is proportion gain coefficient, $k_{i}$ is integration time coefficient, $k_{d}$ is differential time coefficient.

We are most interested in four major characteristics of the closed - loop response. They are:

- Rise Time: the time it takes for the plant output Y to Rise from $10 \%$ to $90 \%$ of the steady state response.

- Steady state error: the difference between the steady state output and desired output.

- Settling time: the time it takes from the system to coverage to its steady state.

- Overshoot: how much the peak level is higher than the steady state.

The values of $k_{p}, k_{i}$ and $k_{d}$ of PID controller are obtained by using trial-and-error method.

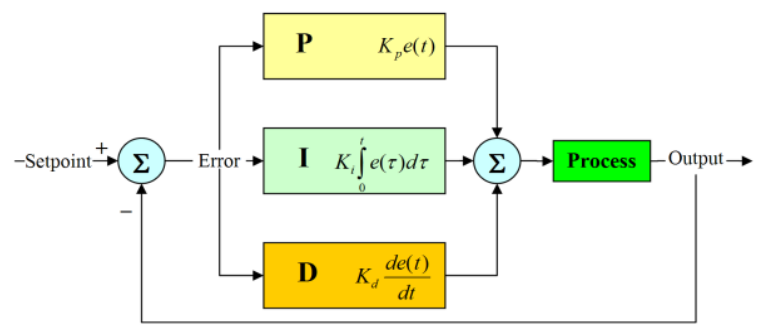

Figure (4): PID controller

\section{B. Fuzzy PID controller}

Fuzzy self-tuning PID controller with error $\mathrm{E}$ and error change rate $\mathrm{CE}$ as input, PID parameters $k_{p}, k_{i}, k_{d}$ as output, $\mathrm{E}$ and CE can satisfy the self-tuning of PID parameters, Using the fuzzy control rules to modify the PID parameters on line. The structure of fuzzy self-tuning PID controller is shown in Fig. (5) [5].

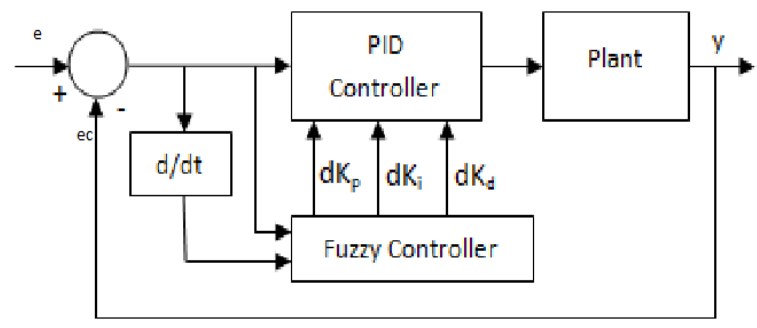

Figure (5): Fuzzy self-tuning Controller

The amount of the deviation $\mathrm{E}$ of input and error change rate $\mathrm{CE}$ and output $\Delta k_{p}, \Delta k_{i}, \Delta k_{d}$ make fuzzy processing, Fuzzy sets were described using following linguistic labels Positive Very Small (PVS), Positive Small (PS), Positive (P), Positive Medium (PM) Positive Large (PL) and Positive Very Large (PVL).Output here $\Delta k_{p}, \Delta k_{i}, \Delta k_{d}$ namely the amount of change $k_{p}, k_{i}, k_{d}$ 's. Input and output variables are selected Gaussian membership functions. The use of MATLAB GUI design
Mamdani fuzzy controller, obtain themembership function of each fuzzy subset Fig.6 to8 [6].

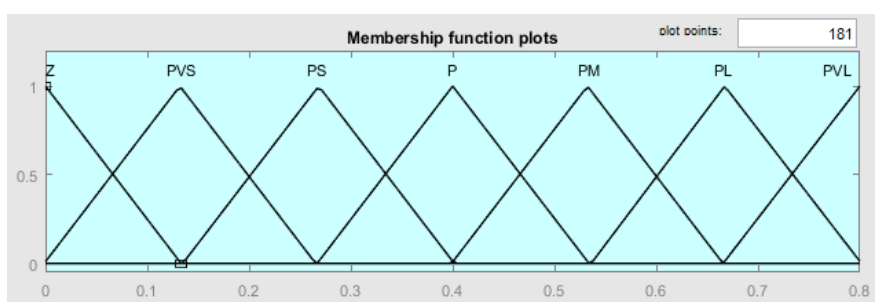

Figure (6): The membership of $\Delta k_{p}$

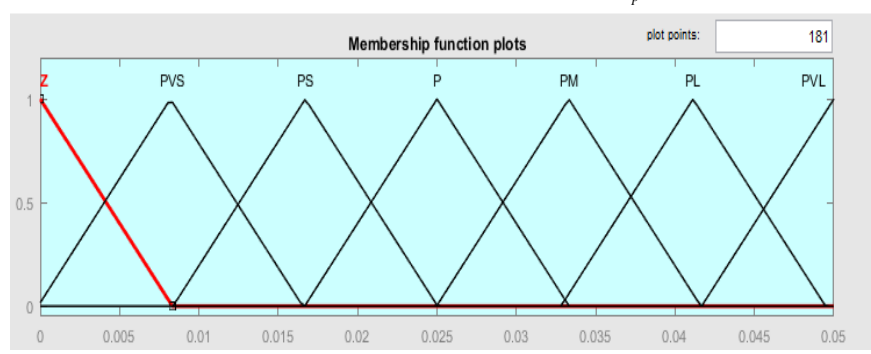

Figure (7): The membership of $\Delta k_{i}$

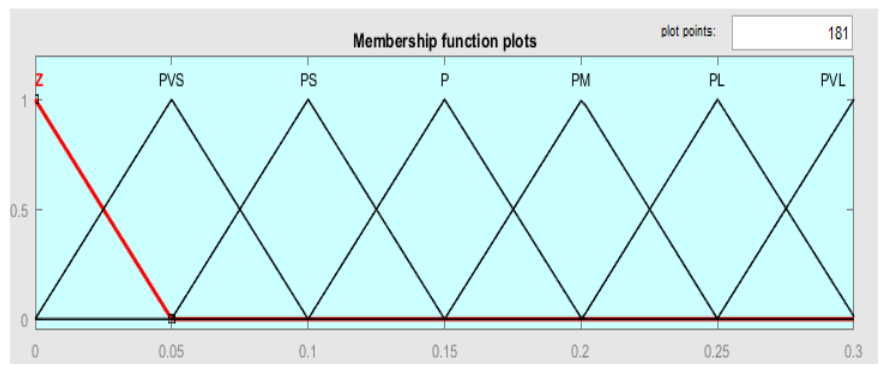

Figure (8): The membership of $\Delta k_{d}$

For speed control system of brushless DC motor, taking into account the effect of contact time three different parameters and between [6], summarized based on actual operating experience, the establishment $\Delta k_{p}, \Delta k_{i} \Delta k_{d}$ fuzzy control rules as shown in Table II, III and IV. The proposal Fuzzy PID controller is shown in fig. 13 [7].

TABLE II FUZZY RULES FOR $\Delta k_{p}$

\begin{tabular}{|c|c|c|c|c|c|c|c|}
\hline $\mathrm{E} / \mathrm{CE}$ & $\mathrm{NB}$ & $\mathrm{NM}$ & $\mathrm{NS}$ & $\mathrm{Z}$ & $\mathrm{PS}$ & $\mathrm{PM}$ & $\mathrm{PB}$ \\
\hline $\mathrm{NB}$ & $\mathrm{PVL}$ & $\mathrm{PVL}$ & $\mathrm{PL}$ & $\mathrm{PL}$ & $\mathrm{PM}$ & $\mathrm{PM}$ & $\mathrm{P}$ \\
\hline $\mathrm{NM}$ & $\mathrm{PVL}$ & $\mathrm{PVL}$ & $\mathrm{PL}$ & $\mathrm{PM}$ & $\mathrm{PM}$ & $\mathrm{P}$ & $\mathrm{PS}$ \\
\hline $\mathrm{NS}$ & $\mathrm{PVL}$ & $\mathrm{PL}$ & $\mathrm{PL}$ & $\mathrm{PM}$ & $\mathrm{P}$ & $\mathrm{PS}$ & $\mathrm{PS}$ \\
\hline $\mathrm{Z}$ & $\mathrm{PL}$ & $\mathrm{PL}$ & $\mathrm{PM}$ & $\mathrm{P}$ & $\mathrm{PS}$ & $\mathrm{PVS}$ & $\mathrm{PVS}$ \\
\hline $\mathrm{PS}$ & $\mathrm{PM}$ & $\mathrm{PM}$ & $\mathrm{P}$ & $\mathrm{PS}$ & $\mathrm{PS}$ & $\mathrm{PVS}$ & $\mathrm{PVS}$ \\
\hline $\mathrm{PM}$ & $\mathrm{PM}$ & $\mathrm{P}$ & $\mathrm{PS}$ & $\mathrm{PVS}$ & $\mathrm{PVS}$ & $\mathrm{PVS}$ & $\mathrm{Z}$ \\
\hline $\mathrm{PB}$ & $\mathrm{P}$ & $\mathrm{PS}$ & $\mathrm{PS}$ & $\mathrm{PVS}$ & $\mathrm{PVS}$ & $\mathrm{Z}$ & $\mathrm{Z}$ \\
\hline
\end{tabular}


TABLE III FUZZY RULES FOR $\Delta k_{i}$

\begin{tabular}{|c|c|c|c|c|c|c|c|}
\hline $\mathrm{E} / \mathrm{CE}$ & $\mathrm{NB}$ & $\mathrm{NM}$ & $\mathrm{NS}$ & $\mathrm{Z}$ & $\mathrm{PS}$ & $\mathrm{PM}$ & $\mathrm{PB}$ \\
\hline $\mathrm{NB}$ & $\mathrm{Z}$ & $\mathrm{Z}$ & $\mathrm{PVS}$ & $\mathrm{PVS}$ & $\mathrm{PS}$ & $\mathrm{P}$ & $\mathrm{P}$ \\
\hline $\mathrm{NM}$ & $\mathrm{Z}$ & $\mathrm{Z}$ & $\mathrm{PVS}$ & $\mathrm{PS}$ & $\mathrm{PS}$ & $\mathrm{P}$ & $\mathrm{P}$ \\
\hline $\mathrm{NS}$ & $\mathrm{Z}$ & $\mathrm{PVS}$ & $\mathrm{PS}$ & $\mathrm{PS}$ & $\mathrm{P}$ & $\mathrm{PM}$ & $\mathrm{PM}$ \\
\hline $\mathrm{Z}$ & $\mathrm{PVS}$ & $\mathrm{PVS}$ & $\mathrm{PS}$ & $\mathrm{P}$ & $\mathrm{PS}$ & $\mathrm{PL}$ & $\mathrm{PL}$ \\
\hline $\mathrm{PS}$ & $\mathrm{PVS}$ & $\mathrm{PS}$ & $\mathrm{P}$ & $\mathrm{PM}$ & $\mathrm{PM}$ & $\mathrm{PL}$ & $\mathrm{PVL}$ \\
\hline $\mathrm{PM}$ & $\mathrm{P}$ & $\mathrm{P}$ & $\mathrm{PM}$ & $\mathrm{PM}$ & $\mathrm{PL}$ & $\mathrm{PVL}$ & $\mathrm{PVL}$ \\
\hline $\mathrm{PB}$ & $\mathrm{P}$ & $\mathrm{P}$ & $\mathrm{PM}$ & $\mathrm{PL}$ & $\mathrm{PL}$ & $\mathrm{PVL}$ & $\mathrm{PVL}$ \\
\hline
\end{tabular}

TABLE IV FUZZY RULES FOR $\Delta k_{d}$

\begin{tabular}{|c|c|c|c|c|c|c|c|}
\hline E/CE & NB & NM & NS & $Z$ & PS & PM & PB \\
\hline NB & PM & PS & $Z$ & $Z$ & $Z$ & PVS & PM \\
\hline NM & PM & PS & $Z$ & PVS & PVS & PS & P \\
\hline NS & P & PS & Z & PVS & PS & PS & P \\
\hline Z & P & PS & PS & PS & PS & PS & P \\
\hline PS & P & P & P & P & P & P & P \\
\hline PM & PVL & PS & PM & PM & PM & PM & PVL \\
\hline PB & PVL & PL & PL & PL & PM & PM & PVL \\
\hline
\end{tabular}

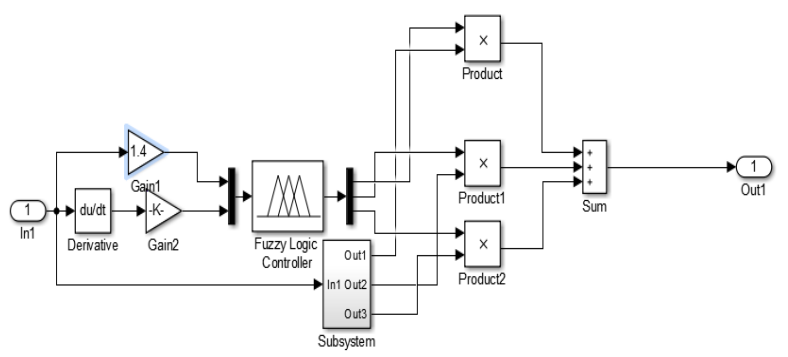

Figure (13): The simulation of Fuzzy PID controller

\section{SIMULATION AND RESULTS}

In this paper, the system design in MATLAB /SIMULINK environment is used to investigate the speed control of BLDC motor using Conventional PID controller and Fuzzy PID controller, the parameters of BLDC motor as shown in table V.To assay the performance of the system, a sequence of measurements has been accomplished. Comparison between PID controller and Fuzzy PID controller of three phases BLDC Motor is shown in table VI [8-9-10].
TABLE V BLDC Motor Parameters

\begin{tabular}{|c|c|c|c|}
\hline Rating & Symbol & Value & units \\
\hline DC resistance & $\mathrm{R}$ & 0.57 & $\Omega$ \\
\hline Inductance & $\mathrm{L}$ & 1.5 & $\mathrm{mH}$ \\
\hline Rated torque & $T_{P}$ & 0.42 & $\mathrm{~N} . \mathrm{M}$ \\
\hline Rated voltage & $\mathrm{V}$ & 36 & $\mathrm{~V}$ \\
\hline Rated speed & $\mathrm{W}$ & 4000 & $\mathrm{RPM}$ \\
\hline Rated current & $\mathrm{I}$ & 5 & $\mathrm{~A}$ \\
\hline $\begin{array}{c}\text { Rotor inertia } \\
\text { Friction } \\
\text { coefficient }\end{array}$ & $\mathrm{J}$ & $23 e^{-6}$ & $\mathrm{Kg} . m^{2}$ \\
\hline $\begin{array}{c}\text { Torque constant } \\
\text { No. of poles }\end{array}$ & $B_{V}$ & 0.0000735 & N.M.S \\
\hline \multicolumn{2}{|c|}{$k_{T}$} & 0.082 & N.m/A \\
\hline
\end{tabular}

TABLE VI THE TRANSIENT PARAMETER OF BLDCM SPEED RESPONSE

\begin{tabular}{|c|c|c|c|c|c|c|}
\hline \multirow{3}{*}{ Speed } & \multirow{2}{*}{\multicolumn{3}{|c|}{ PID controller }} & \multirow{2}{*}{\multicolumn{3}{|c|}{ Fuzzy PID controller }} \\
\hline & & & & & & \\
\hline & $T r$ & $T s$ & O.S\% & $\operatorname{Tr}$ & $T s$ & o.S\% \\
\hline $\begin{array}{l}4000 \text { no } \\
\text { Load }\end{array}$ & 0.0043 & 0.0454 & 14.2 & 0.0036 & 0.006 & 1.12 \\
\hline $\begin{array}{c}3000 \text { no } \\
\text { Load }\end{array}$ & 0.004 & 0.0430 & 12.6 & 0.0031 & 0.0052 & 0.93 \\
\hline $\begin{array}{c}2000 \text { no } \\
\text { Load }\end{array}$ & 0.0039 & 0.041 & 11.3 & 0.0026 & 0.0043 & 0.72 \\
\hline 4000 Load & 0.0043 & 0.0453 & 14.2 & 0.0036 & 0.006 & 1.1 \\
\hline 3000 Load & 0.004 & 0.0432 & 12.65 & 0.0031 & 0.0051 & 1.04 \\
\hline 2000 Load & 0.0039 & 0.0413 & 11.3 & 0.0026 & 0.0043 & 0.78 \\
\hline $\begin{array}{c}4000-3500 \\
\text { Load } \\
\end{array}$ & 0.0034 & 0.6041 & 30.58 & 0.0031 & 0.6034 & 15.54 \\
\hline $\begin{array}{c}3000-2500 \\
\text { Load } \\
\end{array}$ & 0.0029 & 0.6045 & 35.15 & 0.0024 & 0.6038 & 21.18 \\
\hline $\begin{array}{c}\text { 2000-1500 } \\
\text { Load }\end{array}$ & 0.0042 & 1.2 & 48.37 & 0.0017 & 1.2 & 34.36 \\
\hline
\end{tabular}

The performance of the PID controller and Fuzzy PID controller of BLDC Motor on the reference speed of 4000rpm with no load condition is shown in fig. 9-10 (a) speed and (b) torque.

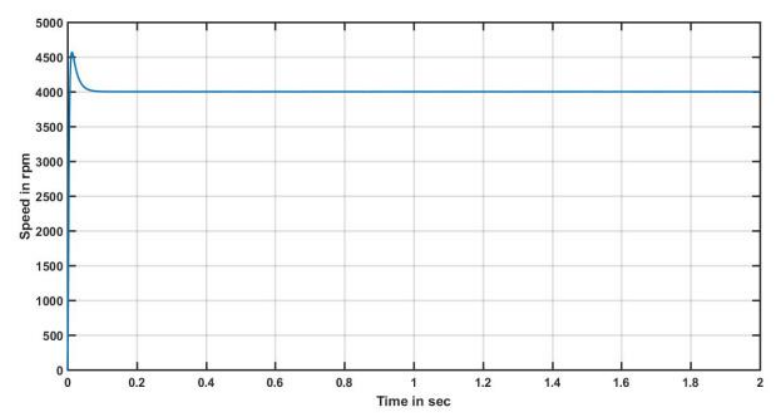

(a) 


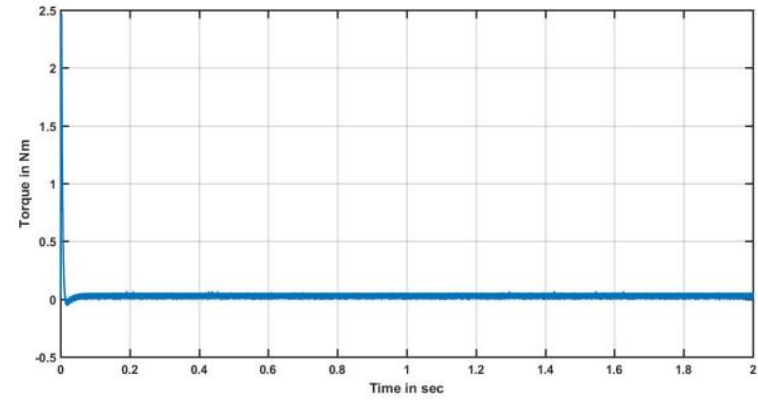

(b)

Figure (9): PID controller at reference speed of 4000rpm with no load (a) speed and (b) load

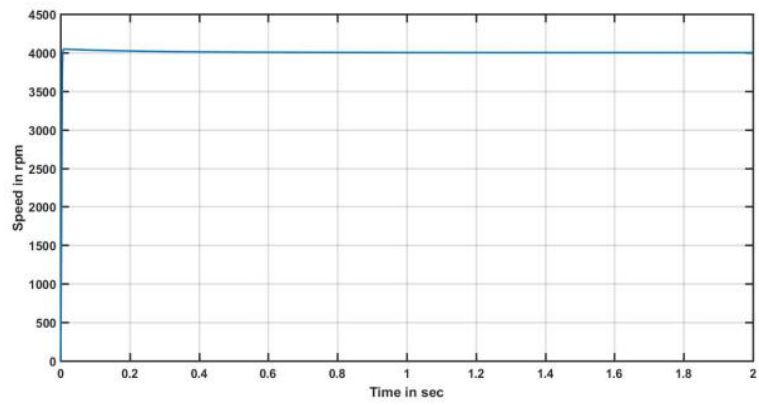

(a)

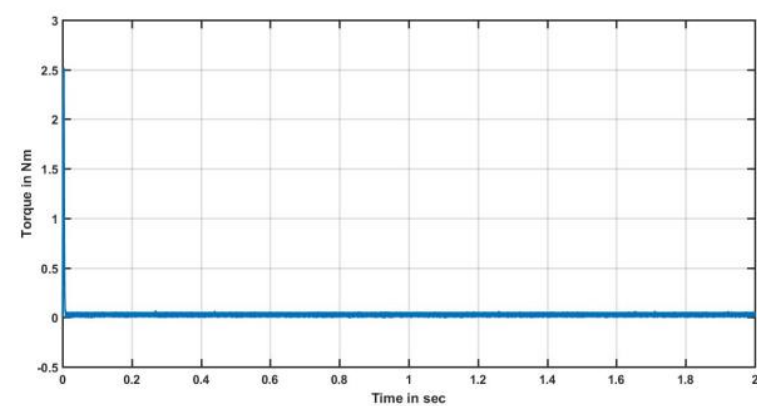

(b)

Figure (10): Fuzzy PID controller at reference speed of 4000rpm with no load (a) speed and (b) load

From the simulation result the PID controller reach settling time is $0.0454 \mathrm{sec}$ but in fuzzy PID controller reach settling time is $0.006 \mathrm{sec}$.

The performance of the PID controller and Fuzzy PID controller of BLDC Motor on the reference speed of $4000 \mathrm{rpm}$ with load condition is shown in fig. 11-12 (a) speed and (b) torque. The load is applied at $\mathrm{t}=1.2 \mathrm{~s}, T_{P}=0.4$ N.m.

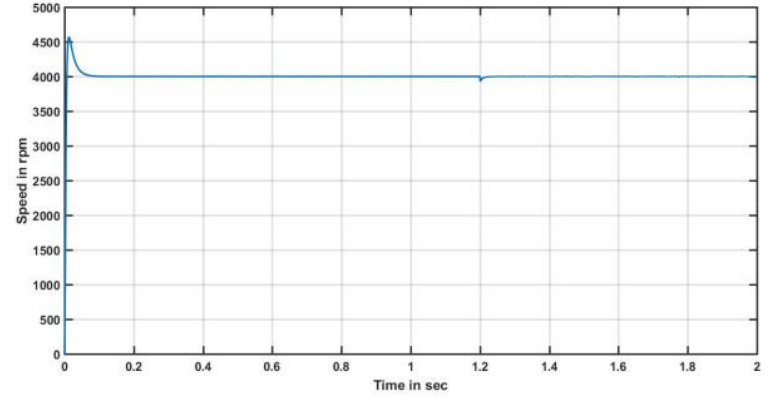

(a)

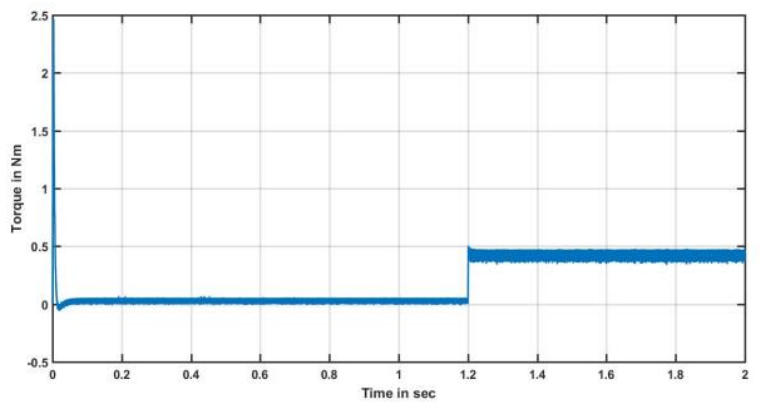

(b)

Figure (11): PID controller at reference speed of 4000rpm with load (a) speed and (b) load

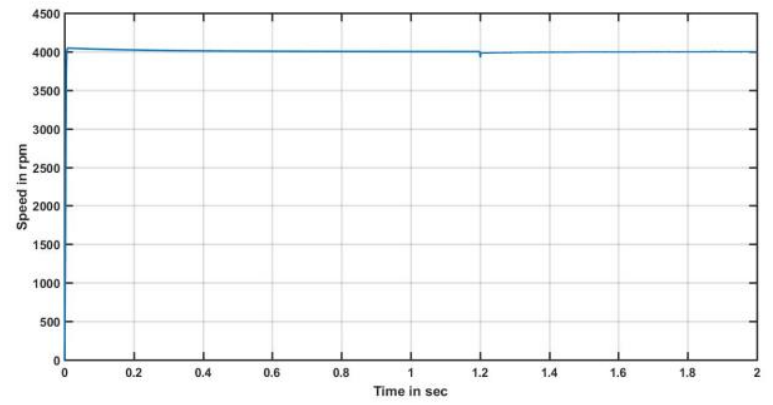

(a)

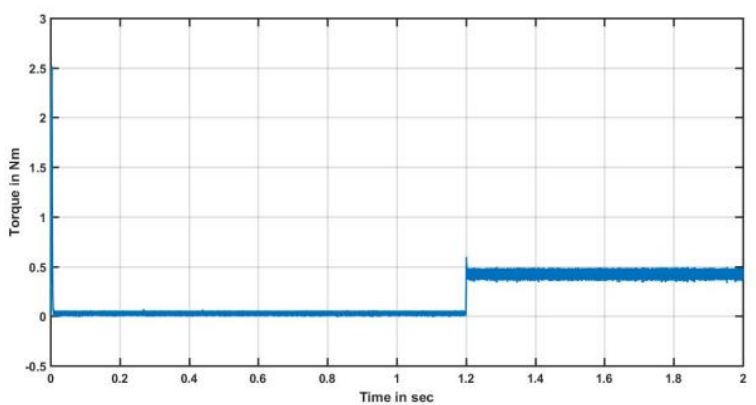

(b)

Figure (12): Fuzzy PID controller at reference speed of 4000rpm with load (a) speed and (b) load

From the simulation result the PID controller reach settling time is $0.0453 \mathrm{sec}$ but in fuzzy PID controller reach settling time is $0.006 \mathrm{sec}$.

The performance of the PID controller and Fuzzy PID controller of BLDC Motor on a step down speed of 4000 - 3500 $\mathrm{rpm}$ with load variation at $\mathrm{t}=1.2 \mathrm{~s}$ is shown in fig. 13-14 (a) speed and (b) torque. 


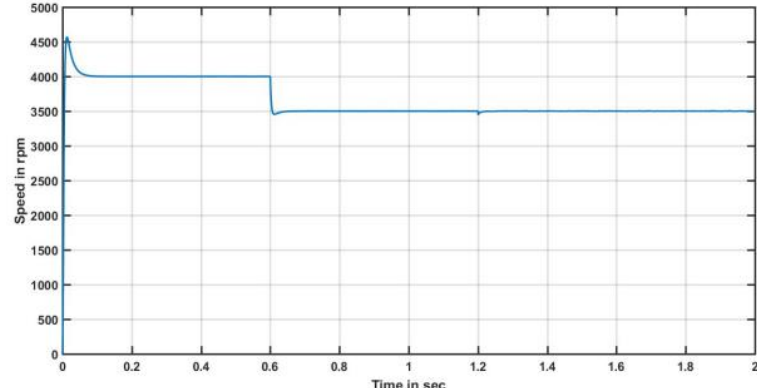

(a)

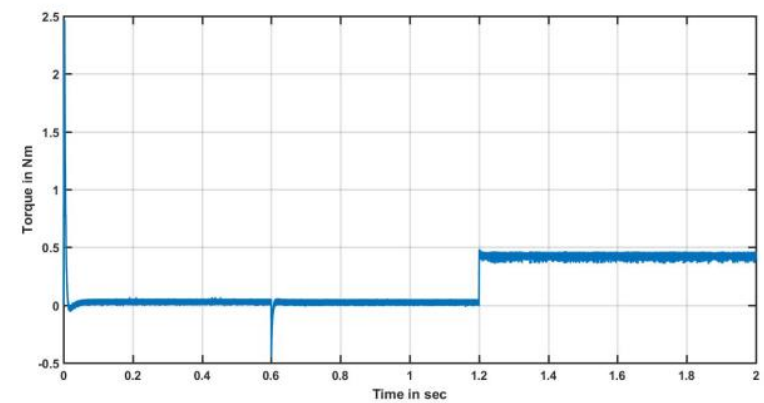

(b)

Figure (13): PID controller at step down of $40003500 \mathrm{rpm}$ with load (a) speed and (b) load

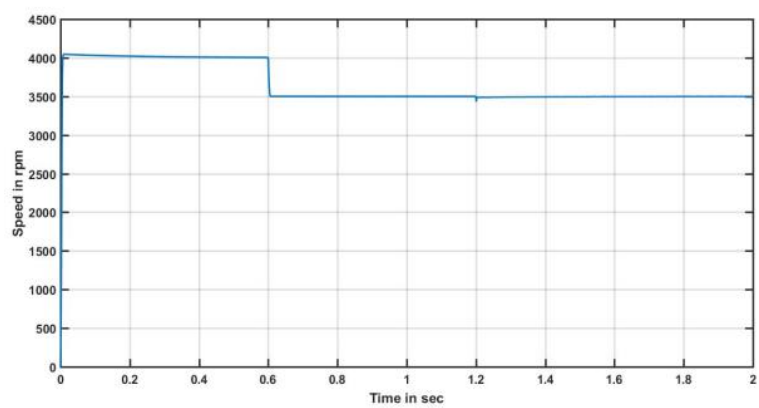

(a)

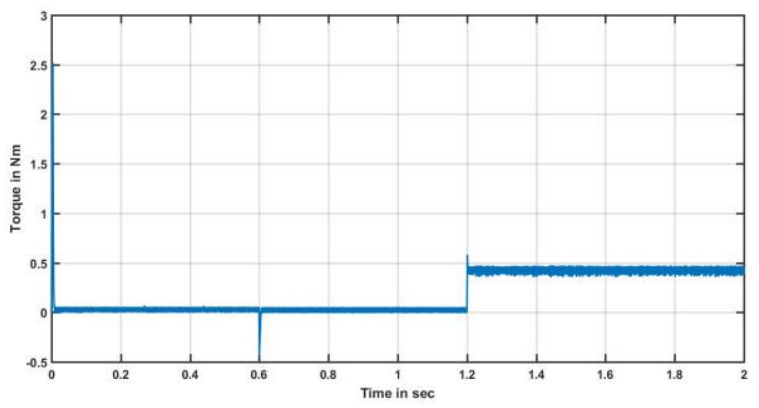

(b)

Figure (14): Fuzzy PID controller at step down speed of 4000-3500 rpm with load (a) speed and (b) load
From the simulation result the PID controller reach settling time is $0.6041 \mathrm{sec}$ but in fuzzy PID controller reach settling time is $0.6034 \mathrm{sec}$

\section{CONCLUTIONS AND FUTURE WORK}

In this paper, the design of speed controller system of BLDC motor using the PID and Fuzzy PID controller has been presented. The results of the simulation shown that the Fuzzy PID controller has a better performance, including a fast response speed, a small amount of overshoot, improve control accuracy and enhanced system robustness.

\section{REFERENCES}

[1] J. Zhao and Y. Yu, Brushless DC motor fundamentals, AN047, July 2011.

[2] J. E. Muralidhar and P. Varanasi, "Torque Ripple Minimization \& Closed Loop Speed Control of BLDC Motor with Hysteresis Current Controller," international conference on devices circuits and systems, 2014

[3] F. Aghili, M. Buehler, and J. M. Hollerbach, "Experimental characterization and quadratic programming-based control of brushless motors," IEEE Trans. Control Syst. Technol. Jan. 2003

[4] P. Ma, W. Liu, Sh. Mao, J. Peng, and G. Luo, "Torque Ripple Reduction in Three-stage Brushless Synchronous Motor Based on $\alpha-\beta-\gamma$ Filter," international Conference on Electrical Machines and Systems (ICEMS). Oct. 22-25, 2014, Hangzhou, China.

[5] M. A. Shamseldin and A. A. Samahy, "Speed Control of BLDC Motor By Using PID Control and Self-tuning Fuzzy PID Controller," 15th International Workshop on Research and Education in Mechatronics, Elgouna, Egypt, September 9-11, 2014.

[6] E. Blessy and M. Murugan, "Modeling and Controlling of BLDC Motor Based Fuzzy Logic," international conference on information communication and embedded system, India, 27-28 Feb. 2014

[7] R. Shanmugasundram, K. M. Zakariah, and N. Yadaiah,” Low cost high performance brushless dc motor drive for speed control applications," in Proc. IEEE Int. Conf. Adv. Recent Technol. Common. Computer, Kottayam, India, Oct. 27-28, 2009.

[8] P. K. Khanke and S. D. Jain, "Comparative Analysis of Speed Control of BLDC Motor Using PI, Simple FLC and Fuzzy - PI Controller," International Conference on Energy Systems and Applications, Pune, India, 30 Oct - 01 Nov, 2015.

[9] S. Zhang and Y. Wang, "The Simulation of BLDC Motor Speed Control Based-Optimized Fuzzy PID Algorithm,” International Conference on Mechatronics and Automation Harbin, China, August $7-102016$.

[10] M.A. shamseldin, A.A. EL-Samahy and A.M. Abdel Ghany, "Different techniques of self-tuning FOPID control for Brushless DC motor," power systems conference, Cairo, Egypt, 27-29 Dec. 2016. 